\title{
Lagophthalmos or Hare Eye: An Etymologic Eye Opener
}

\author{
Robert C. Van de Graaf · Frank F. A. IJpma • \\ Jean-Philippe A. Nicolai
}

Received: 8 January 2008 / Accepted: 22 February 2008/Published online: 20 March 2008

(C) The Author(s) 2008

In their article, on the static treatment of paralytic lagophthalmos with autogenous tissues, Dr Pirrello et al. [1] state: "The word lagophthalmos derives from the Greek terms $\lambda \alpha \gamma o \varsigma$ (hare) and $o \varphi \tau \alpha \lambda \mu o \varsigma$ (eye). It is a condition in which the eyelids are unable to close the palpebral aperture completely and cover the whole eye. Hares in fact sleep with their eyes open." This statement requires some etymologic remarks.

The belief that hares sleep with their eyes open can be found in the literature ever since the ancient Greek and Roman societies [2, 3]. For a long time the hare's habits were hardly known. The hare was a mysterious creature and became the subject to much folklore [2, 4-6]. Nowadays, however, many of the mysteries about the hare are disproved as we are now better able to observe hares with our modern filming techniques [2]. We now know that hares are able to close their eyes and that they do not sleep with their eyes open (Fig. 1) [2, 6, 7].

One of the first to use the medical term lagophthalmos was the Roman encyclopaedist Aulus Cornelius Celsus (ca. $30 \mathrm{BC}$ to ca. $45 \mathrm{AD}$ ) [8, 9]. Celsus defined lagophthalmos as a shortening of solely the upper eyelid, in contrast to ectropion, which he defined as a shortening of the lower eyelid $[8,10]$. It is interesting to notice that ever since its first use there seems to have been no

R. C. Van de Graaf $(\bowtie) \cdot$ J.-P. A. Nicolai

Department of Plastic Surgery,

University Medical Center Groningen,

Hanzeplein 1, P.O. Box 30001, Groningen 9700 RB,

The Netherlands

e-mail: Robertcvandegraaf@histplastsurg.com

F. F. A. IJpma

Department of Surgery, Isala Clinic, Zwolle, The Netherlands

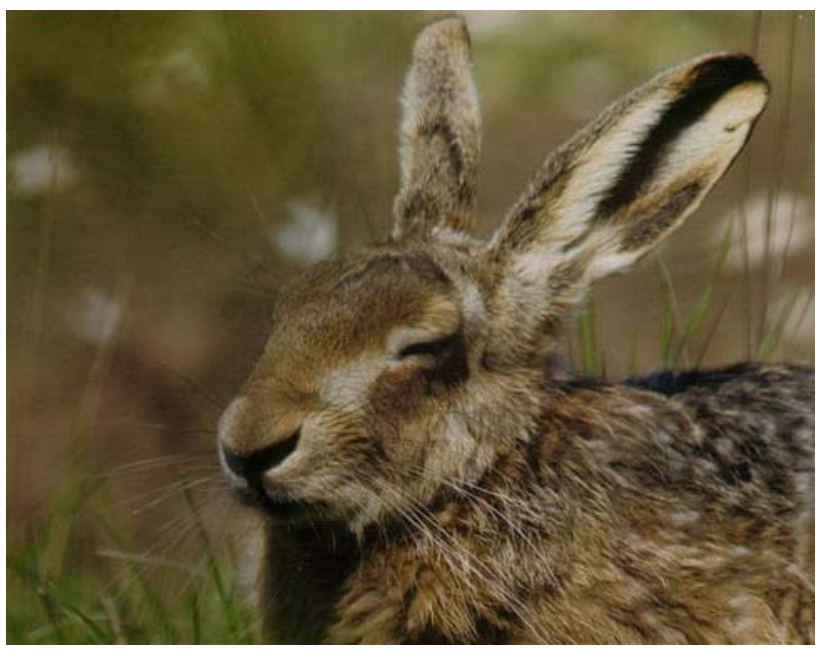

Fig. 1 A hare with its eye closed (with permission from Mason [7])

consensus on whether lagophthalmos should be defined as an affection of the upper eyelid, the lower eyelid, or both. Moreover, the terms lagophthalmos and ectropion were mixed up [11].

Today, there finally seems to be consensus. Lagophthalmos is defined as the inability to close the eyelids [1]. The current definition is based on the ancient belief that hares sleep with their eyes open. However, from a biological point of view this definition is astonishing, since now we designate patients who are unable to close their eyes as having hare eyes, while hares in fact sleep with their eyes closed.

Open Access This article is distributed under the terms of the Creative Commons Attribution Noncommercial License which permits any noncommercial use, distribution, and reproduction in any medium, provided the original author(s) and source are credited. 


\section{References}

1. Pirrello R, D'Arpa S, Moschella F (2007) Static treatment of paralytic lagophthalmos with autogenous tissues. Aesth Plast Surg 31:725-731

2. Phillips AA, Willcock MM (1999) Xenophon \& Arrian on hunting with hounds. Aris \& Phillips Ltd, Warminster, England

3. Scholfield AF (1971) Aelian on the characteristics of animals. Harvard University Press, Cambridge, MA

4. Evans GD, Thomson D (2002) The leaping hare. Faber and Faber Ltd, London, England

5. Grzimek B (1973) Het leven der dieren, encyclopedie van het dierenrijk. Uitgeverij Het Spectrum B.V., Utrecht, The Netherlands
6. Huber J (2004) Heer Lampe, De Europese Haas in Nederland. Koninklijke Vermande, The Hague, The Netherlands

7. Mason J (2005) The Hare. Merlin Unwin Books, Ludlow, Shropshire, UK

8. Blodi FC (1982) Julius Hirschberg, The History of Ophthalmology. J.P.Wayenborgh Verlag, Bonn, Germany

9. Hirschberg J (1887) Wörterbuch der Augenheilkunde. Verlag von Veit \& Comp., Leipzig, Germany

10. Spencer WG (1971) Celsus, De Medicina. Harvard University Press, Cambridge, MA

11. Von Ammon FA (1831) Observations on Lagophthalmos and Ectropium from caries of the margin of the orbit, and Synechia thence arising. Maryland Med Rec 2:181-187 